\title{
EMPLOYEE PERFORMANCE ANALYSIS BASED ON HUMAN RESOURCES MANAGEMENT PRACTICES IN PRIVATE HOSPITAL IN SURAKARTA
}

\author{
Rini Handayani \\ Department of Management, Atma Bhakti Institute of Economics, Surakarta, Indonesia \\ Email: rini.handayani@stie-atmabhakti.ac.id (corresponding author)

\section{Kasidin} \\ Department of Management, Atma Bhakti Institute of Economics, Surakarta, Indonesia \\ Email:kasidin@stie-atmabhakti.ac.id
}

Received: September 2021; Accepted: December 2021; Available online: January 2022

\begin{abstract}
Human resource management (HRM) is the foundation to face business competition. Organizational strategies related to HRM create satisfaction among employees so that employees perform well and can create a competitive advantage for their organization. The need for human resources in the hospital industry has developed along with the availability of hospitals reaching 2813 hospitals in Indonesia. This of course requires superior human resources performance. HRM practices are expected to drive human resources performance and achieve a competitive advantage in the hospital industry. This study will examine the effect of HRM practices, namely training, performance appraisal, and compensation systems on employee performance. Furthermore, this study will also examine the role of job satisfaction to mediate HRM practices on employee performance. The study was conducted in a private hospital in the Surakarta area with a sample of 120 respondents. Convenience sampling technique as a sampling method used to collect samples using a questionnaire. SmartPLS is used to analyze research data. The results showed that there was a significant positive effect on HRM Practices (training, performance appraisal, compensation system) on employee performance. However, job satisfaction only mediates the effect of performance appraisal and compensation system on employee performance, while job satisfaction does not play a role in mediating the effect of training on employee performance.
\end{abstract}

Keywords: HRM Practices; Training; Performance Appraisal; Compensation Systems; Employee Performance.

\begin{abstract}
Abstrak
Manajemen sumber daya manusia (SDM) menjadi pondasi untuk menghadapi pesaingan bisnis. Strategi organisasi yang terkait dengan manajemen SDM menciptakan kepuasan di antara karyawan sehingga karyawan berkinerja baik dan mampu menciptakan keunggulan kompetitif bagi organisasinya. Kebutuhan SDM pada industri rumah sakit mengalami perkembangan seiring dengan tersedianya rumah sakit mencapai 2813 rumah sakit di Indonesia. Hal ini tentu membutuhkan kinerja SDM yang unggul. Praktek manajemen SDM diharapkan dapat sebagai pendorong kinerja SDM dan mencapai keunggulan kompetitif industri rumah sakit. Penelitian ini akan menguji pengaruh praktek manajemen SDM yaitu training, penilaian kinerja, dan system kompensasi terhadap kinerja karyawan. Selanjutnya penelitian ini juga akan menguji peran kepuasan kerja untuk memediasi Praktek Manajemen SDM terhadap kinerja karyawan. Penelitian dilakukan di rumah sakit swasta wilayah Surakarta dengan sampel sebanyak 120 responden. Teknik convenience sampling sebagai metode sampling yang digunakan dengan pengumpulan sample menggunakan kuesioner. SmartPLS digunakan untuk menganalisis data penelitian. Hasil penelitian menunjukan adanya pengaruh positif signifikan pada Praktek Manajemen SDM (training, penilaian kinerja, sistem kompensasi) terhadap kinerja karyawan.Namun kepuasan kerja hanya memediasi pengaruh penilaian kinerja dan system kompensasi terhadap kinerja karyawan sedangkan kepuasan kerja tidak berperan memediasi pengaruh training terhadap kinerja karyawan.
\end{abstract}

Katakunci: Praktek Manajemen Sumber Daya Manusia; Training; Penilaian Kinerja; Sistem Kompensasi; Kinerja Karyawan 
How to Cite: Handayani, R. \& Kasidin, K. (2022). Employee Performance Analysis Based on Human Resources Management Practices in Private Hospital in Surakarta. Media Ekonomi dan Manajemen, 37(1), 109-126. doi: http://dx.doi.org/10.24856/mem.v37i1.2428.

\section{INTRODUCTION}

The dynamic business environment requires every organization to maximize its strategic capabilities to take advantage of business opportunities and achieve superior performance compared to its business competitors. Human resources, as organizational resources, are critical in ensuring that an organization's backbone is strong enough to obtain a competitive advantage in the marketplace. Effectiveness of human resource management is needed to support organizational performance, for that employees as the main organizational resources are in a strategic position to be able to create a competitive advantage (Allameh et al., 2014; Khan, 2010; Taib et al., 2018) because human resources in each organization vary, they have unique characteristics and cannot be imitated (Shaukat et al., 2015). Effective human resource management practices directly impact the performance of an organization and its ability to obtain a competitive edge (Chukwuka Ernest J., 2016; Rawashdeh \& Al-Adwan, 2012). This is a fact that human resources play an essential role in managing the life and long-term viability of a company's operations since human resources are responsible for carrying out the organization's policies, programs, objectives, and goals. Good human resource management practices (HRMP) contributes to the creation of a good organizational climate so that it will provide opportunities for the development and proper distribution of work for members of the organization and create a pleasant working relationship.

Research on HRMP in developing countries so far has received less attention (Aycan et al., 2000; Hassan, 2016; Mahadevan \& Mohamed, 2014). Even some studies show that employee performance is not influenced by HRMP, for example training (Azis. et al., 2019; Ingsih et al., 2021), performance appraisal
(Japlani. A. \& Purnamasari, 2020; Subekti, 2021), compensation system (Hee \& Jing, 2018; Shanty \& Mayangsari, 2017). This causes the company to pay less attention to the company's HRMP. However, several studies provide results that point to a significant influence of HRMP on organizational performance (Hassan, 2016; Taib et al., 2018). Organizations can adopt HRMP to attract or retain talented members of the organization to achieve their organizational goals (Mohamed, 2014; Nor, 2018).

To strengthen the theory of HRM in developing countries and based on the existing gap research in HRMP on employee performance, job satisfaction is one of the possible variables to mediate research gaps on HRMP and employee performance. HRMP fosters employee confidence so that they can work enthusiastically, optimally and obtain job satisfaction. Kondisi tersebut nantinya akan menumbuhkan efektifitas kerja dan kinerja pegawai serta keunggulan bersaing organisasi (Alsafadi \& Altahat, 2021; Astuti et al., 2020; Pradhan et al., 2017).

Job satisfaction can be interpreted as a person's level of happiness and comfort with the organization or work he does (Rodjam et al., 2020). Employees will feel happier and more comfortable at work if employees are in a good work environment and an organization that supports the achievement of their task completion. In the hospital industry, job satisfaction of hospital staff is very crucial because it will have an impact on excellent service to patients and will have an impact on patient satisfaction, lower medical costs, and will ultimately make hospitals more competitive (Chaudhury, 2015). HRM efforts are needed to be able to build employee job satisfaction which ultimately affects employee and company performance.

In this research, job satisfaction will play a mediating role between HRMP and 
employee performance. A good HRMP will foster employee satisfaction at work which in the end the level of comfort and happiness will improve their performance at work. Rodjam et al. (2020) argue that when employees are satisfied, they will do various things that are positive and will have an impact on the success of the organization.

Furthermore, this research will be conducted in the service industry sector, namely private hospitals. Hospitals in Indonesia have tremendous growth. Based on data from the Ministry of Health in March 2019, hospitals reached 2813. This is balanced with the high demand for human resources. Hospital performance, of course, cannot be achieved if it is not supported by the superior performance of its employees because, in hospitals, medical personnel is the arteries that maintain the sustainability of the hospital industry. This causes HRMP to be indispensable in the hospital industry.

HRMP in this study is training, performance appraisal, and compensation system. Management of employees as company resources is expected to be the key to the company's success because it supports the company's business strategy. The purpose of this study was to investigate the impact of human resource management practices (HRMP), which include training, performance appraisal, and remuneration systems, on employee performance in private hospitals, as mediated by job satisfaction. Through the role of the employee job satisfaction construct as a mediation, it is hoped that this research can provide information about human resource management practices and help experts in the HRM field to improve employee performance, especially in the private hospital service industry.

\section{LITERATURE REVIEW Human Resource Management}

Chukwuka Ernest J. (2016) rgues that human resource management considers the dimensions of people as the driving force in the organization. Where every organization is not only formed by people, it will also shape the behavior of the people involved in it, get their services reciprocated, refine their skills, motivate them to achieve superior performance, and ensure that they continue to maintain their commitment to the organization.

A strategic approach needs to be taken to manage working relationships that focus on individual abilities to obtain a sustainable competitive advantage (Jocom et al., 2017). This is achieved through an integrated and unique set of policies, programs, and employment practices (Bratton \& Gold, 2003). HRMP is designed and implemented so that it can attract, motivate and even retain employees. It aims for the sustainable survival of the organization (Schuler \& Jackson, 1987). HRMP expert training (Karim et al., 2019), performance appraisal (Khan. et al., 2018; Rahahleh et al., 2019), compensation system (Onuorah et al., 2019; Siddiqi \& Tangem, 2018) encourage employees to work better to improve organizational performance.

\section{Human Resources Management Practise (HRMP) And Employee Performance}

Rapid changes in the business environment force the business world to adopt HRMP so that they to seize the market and maintain business sustainability testing the influence of HRMP on employee performance has been tested by several studies.

Several studies in various industrial sectors show the influence of HRMP on employee performance (Croucher et al., 2012; Hassan, 2016; Mira et al., 2019; Taib et al., 2018). Most showed a significant effect of increasing employee performance from the HRM practice. Employee performance is an important factor that acts as a driver of organizational performance. A well-executed HRMP will bring organizational success (Nor, 2018; Shaukat et al., 2015). 
Ghebregiorgis and Karsten (2006) argues that the community's economic conditions, political instability and environmental uncertainty will affect HRMP, among others, on recruitment, performance appraisal, training, compensation and reward systems. Carlson et al. (2006) found that providing competitive compensation, attractive recruitment and performance appraisal systems, and providing training \& development to employees all affect employee performance. While Tessema and Soeters (2006) studied eight HRMPs that had a significant and positive effect on perceived performance, including retirement or social security, training, complaint practices, placement, promotion, recruitment and selection, compensation practices, and performance evaluation.

\section{Effect of Training and Employee Performance}

Tzafrir (2005) believes that the training provided to employees is an important part of building human resource competencies. Training is given to make changes through new skills or improve the skills that employees already have. Training can initiate employees in completing their work so that it has an impact on achieving the organization's long-term goals (Laird et al., 2003). Therefore, the company has an interest in designing the right training program so that it fits the needs of employees and the company.

Training plays an important role in creating and improving employee competence and productivity so that later it can produce superior employee performance (Cardon \& Stevens, 2004; Castilla, 2005; Qureshi \& Mohammad, 2006). In addition, training will motivate employees to engage in important organizational activities in order to achieve organizational targets (Bolman \& Deal, 2011). Research shows a significant effect of training on employee performance (Chełmecka, 2018; Jocom et al., 2017;
Karim et al., 2019; Younas et al., 2018; Zhavoronkova et al., 2018).

$\mathrm{H}_{1 \mathrm{a}}$ : Training affects employee performance

Effect of performance appraisal on employee performance

Observations on the impact of the effectiveness of performance appraisal on employees have not been widely carried out, especially in the Asian region (Shahzad et al., 2008). Performance appraisal is a systematic evaluation of the work of employees and aims to motivate employees in carrying out their work (Singh, 2004; Wan et al., 2002). Companies can take advantage of employee performance appraisals to improve employee performance. As stated by Sels (2003) that the performance appraisal set by the company will motivate employees to work more productively and achieve good performance.

Several studies have the opinion that performance appraisal can close the performance gap between employees, therefore clarity is needed in conducting performance appraisals. Accurate and fair performance appraisals focus on employee performance behavior and not on employee personal characteristics (Ghauri, 2012). Performance appraisal has the toughest challenge regarding subjectivity but several researchers have identified a positive influence between performance appraisal on employee performance (Khan, 2010; Khan. et al., 2018; Meysen et al., 2012).

$\mathrm{H}_{1 \mathrm{~b}}$ : Performance appraisal affects employee performance

\section{Effect of Compensation System on employee performance}

Employees are motivated to perform well because of the compensation structure. In exchange for their efforts on behalf of the company, employees receive a salary or other form of remuneration. (Hafiza. N. S et al., 2011) defines compensation as the accumulation of benefits earned by 
employees for their efforts in the organization's job obligations. Salmela-Aro and Nurmi (2004) mention compensation as an extrinsic incentive for certain tasks performed.

Performance-based compensation is an HRMP that is often used to evaluate and reward employees' efforts (Alqudah et al., 2014). Several studies indicate that there is an influence between the compensation system and employee performance (Hafiza. N. S et al., 2011; Hameed, 2014; Siddiqi \& Tangem, 2018).

$\mathrm{H}_{1 \mathrm{c}}$ : $\begin{gathered}\text { Compensation system affects } \\ \text { employee performance }\end{gathered}$

\section{The Role of Job Satisfaction Mediates the Effect of HRMP on Employee Performance}

Employee job satisfaction will be achieved if the expectations or benefits desired by employees can be realized after they do what is their obligation or duty. George and Zakkariya (2018) argue that job satisfaction is an individual's emotional reaction to the results of his work, namely by comparing the results that have been achieved with the desired results. Individuals when they have achieved job satisfaction will be more enthusiastic about working. Job satisfaction is the key to improving performance that leads to the achievement of organizational goals (Rais et al., 2021). Even an organization with a good work plan will not run well to achieve its goals if the employees involved do not work with pleasure and enthusiasm. Robbins and Judge (2015) also state that happy employees are productive employees. Job satisfaction is one of several factors that can mediate HRMP and employee performance (Alsafadi \& Altahat, 2021; Rodjam et al., 2020).

Research Ingsih et al. (2021) state that employee performance is not affected by the training the company provides for its employees. Employee performance is not directly achieved from various materials delivered during training, but employee performance can be formed when employees find problems at work they will feel happy and comfortable if they can ask colleagues. It can be said that training does not have a direct influence on employee performance, but there needs to be a mediating factor, including satisfaction. This phenomenon is linear with research Azis. et al. (2019) who argues that training has no direct effect on employee performance. Prasetyo (2019) and Alsafadi and Altahat (2021) also argue that training mediated by job satisfaction will affect employee performance.

Performance appraisal is important for organizations to assess employee work results and ensure employees have done work according to the standards set by the organization. In addition, with performance appraisal, the organization can determine what rewards or punishments will be given for employee performance. Appraisal performance has the aim of increasing the level of employee job satisfaction through recognition of the employee's work (Rais et al., 2021). Research from Wandansari (2019) and Ferdiane et al. (2018) stated that performance appraisal can affect employee performance through job satisfaction.

Furthermore, compensation is an important aspect that can also influence individual work behavior. A good compensation system has a positive impact on the organization because it will strengthen the main values of the organization. In addition, organizational goals can be achieved through the establishment of a good compensation system for its employees. Hartono et al. (2021), Sukidi (2016), and Yudianto and Aryani (2018) state that the compensation system affects employee performance through job satisfaction. Compensation given appropriately will foster a sense of satisfaction with the work of employees and will motivate them to achieve organizational targets.

$\mathrm{H}_{2 \mathrm{a}}$ : Job satisfaction mediates the effect of training on employee performance 
$\mathrm{H}_{2 \mathrm{~b}}$ : Job satisfaction mediates the effect of performance appraisal on employee performance

$\mathrm{H}_{2 \mathrm{c}}$ : Job satisfaction mediates effect of compensation system on employee performance

\section{Research Framework}

mployees are a very valuable resource in an organization where the success or even the sustainability of the organization is strongly influenced by employee performance. Therefore, the performance of employees is very important to the organization. HRMP is a management approach that can be used to achieve competitive advantage through human resource development strategies. Several studies have shown that HRMP (training, performance appraisal, compensation system) has a direct influence on employee performance (Hafiza et al., 2011; Hameed, 2014; Karim et al., 2019; Khan. et al., 2018; Siddiqi \& Tangem, 2018; Younas et al., 2018) or through job satisfaction (Alsafadi \& Altahat, 2021; Azis. et al., 2019; Hartono et al., 2021; Ingsih et al., 2021; Yudianto \& Aryani, 2018).

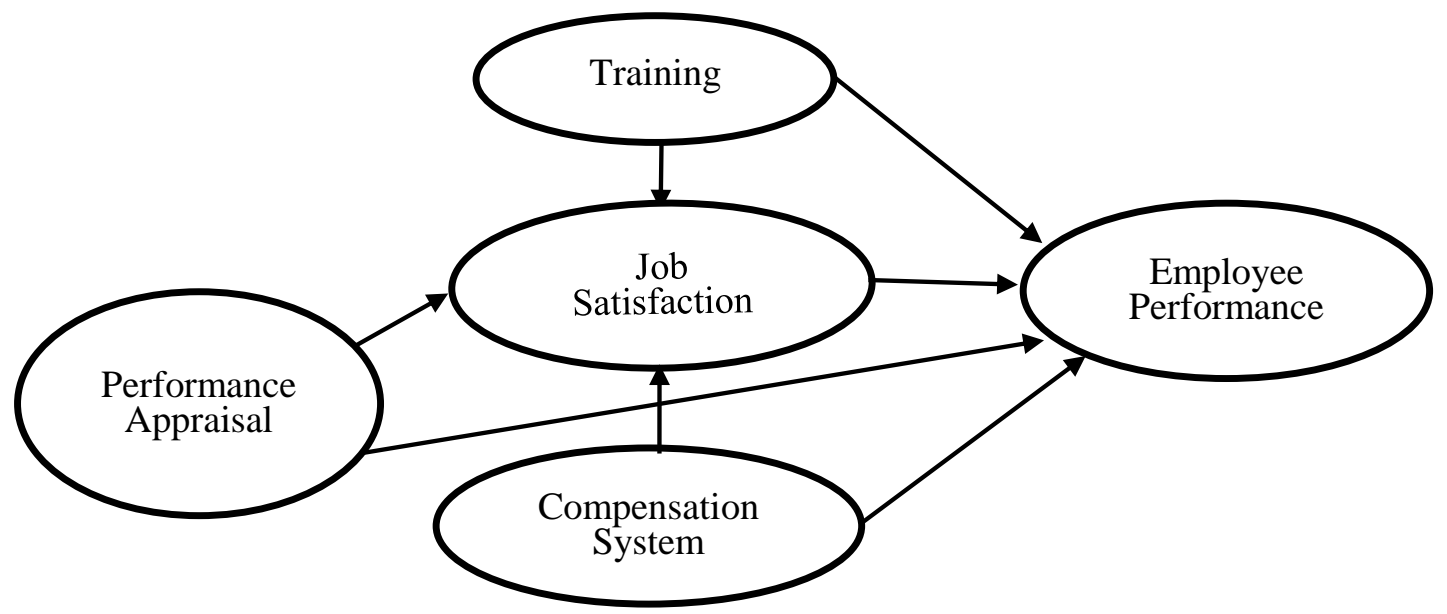

Figure 1. Research Framework

\section{RESEARCH METHODS}

Qualitative research method to determine the direct effect of HRMP (training, performance appraisal, compensation system) on employee performance. In addition, it will also determine the effect of HRMP on employee performance with job satisfaction as a mediating variable. The population of this study was employees who were medical personnel, both doctors and nurses at the Surakarta private general hospital, amounting to 2320 . The technique used for sampling is non-probability sampling. Convenience sampling was chosen because of the limited cost and time in the study.
Questionnaires will be distributed to 9 private hospitals in Surakarta (http://bppsdmk.kemkes.go.id). The number of samples was determined from the Slovin formula with a $90 \%$ confidence level. The sample calculation shows the minimum number of samples is 96 people. However, to anticipate the low response rate in the study, the number of questionnaires distributed was added by $25 \%$ of the minimum required sample so that in the end the number of samples in this study was 120 respondents. This is done so that the adequacy of research data is still met. Data from respondents were collected using a questionnaire. 
Measurement of the research instrument with a 5-point Likert scale collected from respondents' responses to evaluate the influence between constructs. Employee performance is defined as the overall result of individual work compared to the targets and responsibilities that have been set and agreed upon in advance (Siddiqi \& Tangem, 2018). Employee performance will be measured by 5 indicators. Training is defined as a systematic approach so that individuals can achieve the knowledge and skills to complete tasks effectively by increasing the resulting behavior (Hassan, 2016). Training will be measured by 4 indicators. The compensation system is a system that regulates the process of giving salaries or wages to individuals for the work they have done (Hassan, 2016). The compensation system will be measured by 5 indicators, namely adequate salary, driving quality of work, routine salary increases, giving bonuses, good work benefits. Performance appraisal is defined as a systematic evaluation of the work of individuals in carrying out the work assigned to them (Hassan, 2016). Performance appraisal is measured by 5 indicators, namely objective and measurable results, achievement of documented performance goals, as well as work efficiency and effectiveness. Job satisfaction is the level of happiness of employees regarding the tasks they carry out and the conditions of the organization (Rodjam et al., 2020). Job satisfaction will be measured by 4 indicators, namely the job itself, promotion opportunities, fairness in supervision, and co-workers (Ingsih et al., 2021).

Hypothesis testing using Structural Equation Model with SmartPLS 3.0 program. Test the quality of the data using validity and reliability tests. The validity of the data is seen by the convergent validity value which refers to the loading factor above 0.70 . As for reliability testing, see the results of composite reliability and Cronbach's alpha, which is at least 0.6 and a minimum value of 0.5 for Average
Variance Extracted (AVE). Model suitability will be measured by the Goodness of Fit value in the range between $0-1$, namely $0-0.25$ (small category), 0.25 - 0.36 moderate category) and above 0.36 (large category).

The research equation formed is:

$\mathrm{EP}=\mathrm{\gamma}_{0}+\beta_{1} * \mathrm{TR}+\beta_{2} * \mathrm{PA}+\beta_{3} * \mathrm{CS}+\gamma_{1} * \mathrm{JS}+\varepsilon(1)$

Information : JS: Job Satisfaction, TR: Training, PA: Performance Appraisal, CS: Compensation System; EP: Employee Performance

The decision of the hypothesis in the study is based on a significance value of 0.05 and compares the $t$ statistic and t table.

\section{RESULTS AND DISCUSSION Respondent Characteristics}

The characteristics of the 120 respondents are shown in Table 1 . The majority of the respondents were women as many as 68 people $(57 \%)$. The age of the respondents is dominated by respondents who have the age of 31-40 as many as 46 people $(38 \%)$. The education level of respondents for the $\mathrm{S} 1$ level is the most dominant of 47 people (39\%) slightly different from those of the diploma level respondents as many as 38 people (32\%).

\section{Evaluasi Outer Model}

A construct that has composite reliability and Cronbach's alpha values greater than 0.6 is declared a reliable construct (Ghozali. \& Latan, 2015). The results of the reliability test will be presented in table 2 . These results indicate that all constructs have composite reliability and Cronbach's Alpha values above 0.6. The AVE value has shown a value above 0.5 .

The loading instrument value is used to measure convergent validity in the study. It is expected that the minimum loading factor value is 0.7 but if the loading factor value is between $0.5-0.6$ it can still be tolerated (Ghozali. \& Latan, 2015). Figure 2 shows the construct in the study 
has a loading factor value above 0.6. This illustrates that the construct used can be used to measure the model proposed in the study. $\mathrm{n}$ the results of the discriminant validity test, the cross-loading value of the construct will be shown. According to (Ghozali. \& Latan, 2015), if it is found that the correlation of the construct indicators has a higher value than the correlation of these indicators to other constructs, it can be concluded that the construct has high discriminant validity. Table 3 will present cross-loading indicators between constructs.

\section{Evaluation of Inner Model and Outer Loading}

Tests are carried out to see the relationship between the constructs and their significance value. In addition, the value of $\mathrm{N}$ Square is also needed in the evaluation of the inner model to assess the existence of a substantive effect on the exogenous construct on the endogenous construct. Table 4 will present the value of $\mathrm{R}$ Square.

The $\mathrm{R}$ Square value of 0.546 means that the job satisfaction construct can be explained by construct training, performance appraisal, and compensation system by $54.6 \%$ while $45.4 \%$ can be explained by various factors other than the three constructs. Furthermore, the R Square value of 0.803 means that the construct of employee performance can be explained by $80.3 \%$ of the job satisfaction, training, performance appraisal, and compensation system constructs, while $19.7 \%$ can be explained outside the four constructs.

\section{Goodness of Fit (GoF) Test Results}

Testing the suitability of the model is obtained from the multiplication between the average root value of communailities and the average root value of $r$ - square (table 4). The calculation results show a value of 0.657 . These results can be concluded that the research model has a large GoF. A large GoF value indicates a match between the research sample and the proposed model. The results of these calculations are as follows:

$$
\begin{array}{r}
\text { GoF }=\sqrt{\overline{C O M} \times \overline{R^{2}}} \\
=\sqrt{0.6394 \times 0.6745} \\
=\sqrt{0.4313} \\
=0.657
\end{array}
$$

\section{Mediation test results}

The results of the mediation test can be seen from the indirect effect between the constructs of training, performance appraisal and compensation system on employee performance with job satisfaction as a mediating construct. The value of specific indirect effects in the final smartPLS report shows the results of the mediation test (Table 6).

The results of the mediation test show that job satisfaction can act as mediation in the construct performance appraisal, and compensation system on employee performance. This can be seen from the value of the $t$ statistic which is greater than 1.98 and the value of $p$-value which is smaller than 0.05. However, job satisfaction cannot mediate the effect of training on employee performance because the statistical test results show that the statistical $t$ value is smaller than 1.98 and the p-value is greater than 0.05 . 
Table 1. Respondent Characteristics

\begin{tabular}{|c|c|c|}
\hline Information & Amount & Prosentase (\%) \\
\hline \multicolumn{3}{|l|}{ Gender : } \\
\hline - Man & 52 & 43 \\
\hline - Female & 68 & 57 \\
\hline \multicolumn{3}{|l|}{ Age : } \\
\hline$-20-30$ & 20 & 17 \\
\hline$-31-40$ & 46 & 38 \\
\hline$-41-50$ & 33 & 27.5 \\
\hline - $51-60$ & 15 & 12.5 \\
\hline - $\quad$ Over 60 & 6 & 5 \\
\hline \multicolumn{3}{|l|}{ Education : } \\
\hline - Senior High School & 27 & 22 \\
\hline - Diploma & 38 & 32 \\
\hline - Bachelor & 47 & 39 \\
\hline - Master & 8 & 7 \\
\hline
\end{tabular}

Source: Processed data, 2021

Table 2. Reliability Test Results

\begin{tabular}{lccc}
\hline Construct & Composite Reliability & Cronbach's Alpha & AVE \\
\hline Training & 0.884 & 0.826 & 0.655 \\
Performance Appraisal & 0.847 & 0.776 & 0.527 \\
Compensation System & 0.922 & 0.894 & 0.703 \\
Job Satisfaction & 0.871 & 0.803 & 0.628 \\
Employee Performance & 0.915 & 0.884 & 0.685 \\
\hline
\end{tabular}

Source: Processed data, SmartPLS 2021

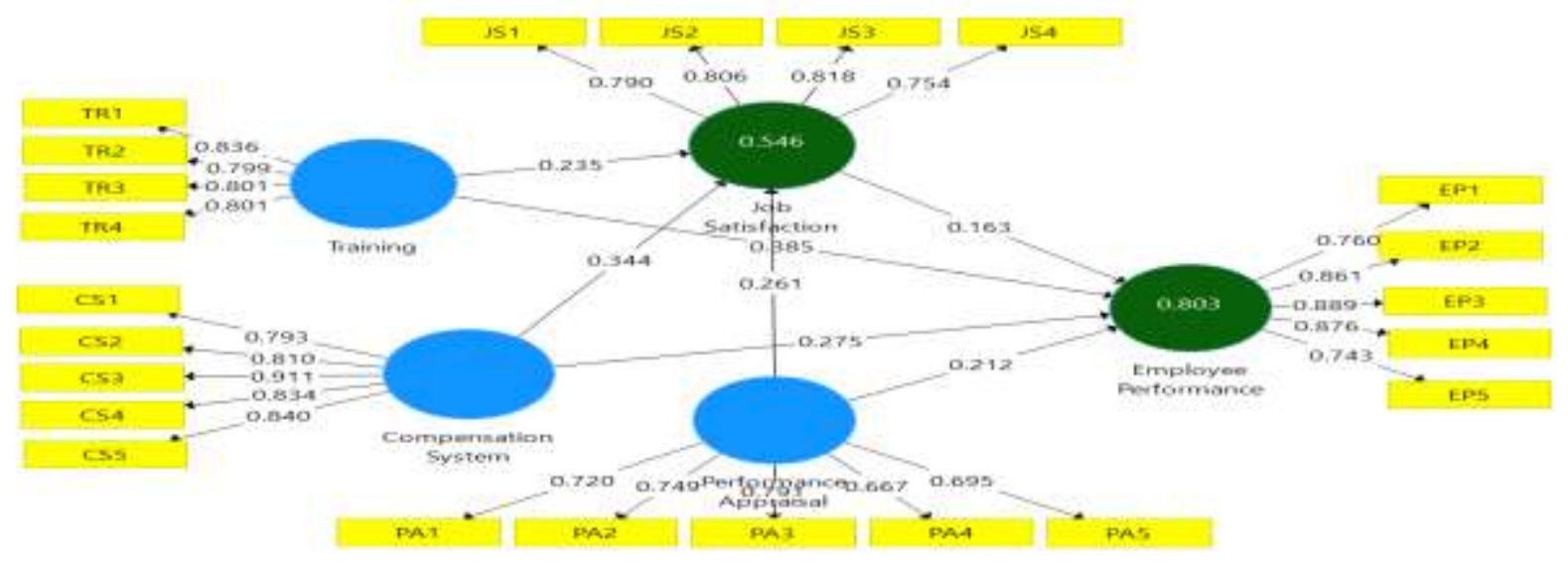

Figure 2. Convergent Validity

Source: Processed data, SmartPLS 2021 
Table 3. Cross Loading Indicators Between Constructs

\begin{tabular}{cccccc}
\hline & Training & $\begin{array}{c}\text { Performance } \\
\text { Appraisal }\end{array}$ & $\begin{array}{c}\text { Compensation } \\
\text { System }\end{array}$ & $\begin{array}{c}\text { Job } \\
\text { Satisfaction }\end{array}$ & $\begin{array}{c}\text { Employee } \\
\text { Performance }\end{array}$ \\
\hline TR 1 & $\mathbf{0 . 8 3 6}$ & 0.508 & 0.529 & 0.552 & 0.636 \\
\hline TR 2 & $\mathbf{0 . 7 9 9}$ & 0.533 & 0.505 & 0.436 & 0.560 \\
\hline TR 3 & $\mathbf{0 . 8 0 1}$ & 0.558 & 0.625 & 0.593 & 0.793 \\
\hline TR 4 & $\mathbf{0 . 8 0 1}$ & 0.435 & 0.573 & 0.457 & 0.601 \\
\hline PA1 & 0.442 & $\mathbf{0 . 7 2 0}$ & 0.378 & 0.358 & 0.453 \\
\hline PA2 & 0.554 & $\mathbf{0 . 7 4 9}$ & 0.455 & 0.376 & 0.577 \\
\hline PA3 & 0.462 & $\mathbf{0 . 7 9 1}$ & 0.553 & 0.483 & 0.534 \\
\hline PA4 & 0.321 & $\mathbf{0 . 6 6 7}$ & 0.398 & 0.427 & 0.437 \\
\hline PA5 & 0.490 & $\mathbf{0 . 6 9 5}$ & 0.481 & 0.582 & 0.610 \\
\hline CS1 & 0.597 & 0.551 & $\mathbf{0 . 7 9 3}$ & 0.551 & 0.703 \\
\hline CS2 & 0.583 & 0.534 & $\mathbf{0 . 8 1 0}$ & 0.484 & 0.583 \\
\hline CS3 & 0.613 & 0.550 & $\mathbf{0 . 9 1 1}$ & 0.655 & 0.691 \\
\hline CS4 & 0.550 & 0.460 & $\mathbf{0 . 8 3 4}$ & 0.481 & 0.696 \\
\hline CS5 & 0.571 & 0.556 & $\mathbf{0 . 8 4 0}$ & 0.632 & 0.614 \\
\hline JS1 & 0.479 & 0.427 & 0.537 & $\mathbf{0 . 7 9 0}$ & 0.512 \\
\hline JS2 & 0.444 & 0,476 & 0.467 & $\mathbf{0 . 8 0 6}$ & 0.510 \\
\hline JS3 & 0.563 & 0.469 & 0.636 & $\mathbf{0 . 8 1 8}$ & 0.625 \\
\hline JS4 & 0.524 & 0.604 & 0.479 & $\mathbf{0 . 7 5 4}$ & 0.633 \\
\hline EP1 & 0.634 & 0.493 & 0.543 & 0.578 & $\mathbf{0 . 7 6 0}$ \\
\hline EP2 & 0.646 & 0.619 & 0.629 & 0.644 & $\mathbf{0 . 8 6 1}$ \\
\hline EP3 & 0.803 & 0.645 & 0.701 & 0.643 & $\mathbf{0 . 8 8 9}$ \\
\hline EP4 & 0.715 & 0.649 & 0.775 & 0.614 & $\mathbf{0 . 8 7 6}$ \\
\hline EP5 & 0.547 & 0.614 & 0.581 & 0.524 & $\mathbf{0 . 7 4 3}$ \\
\hline & & $50 u 4$ & & \\
\hline
\end{tabular}

Source: Processed data, SmartPLS 2021

Tabel 4. Value of R Square

\section{Construct}

Job Satisfaction

Employee Performance

Source: Processed data, SmartPLS 2021
R Square

0.546

0.803

Table 5. Inner Model Statistical Results

\begin{tabular}{lccc}
\hline Construct Causality Relationship & $\begin{array}{c}\text { Estimation } \\
\text { Coefficient }\end{array}$ & t-Statistic & p-Value \\
\hline Training $\rightarrow$ Job Satisfaction & 0.235 & 2.238 & 0.026 \\
Training $\rightarrow$ Employee Performance & 0.385 & 5.046 & 0.000 \\
Performance Appraisal $\rightarrow$ Job Satisfaction & 0.261 & 2.605 & 0.009 \\
Performance Appraisal $\rightarrow$ Employee Performance & 0.212 & 2.728 & 0.007 \\
Compensation System $\rightarrow$ Job Satisfaction & 0.344 & 3.655 & 0.000 \\
Compensation System $\rightarrow$ Employee Performance & 0.275 & 3.311 & 0.001 \\
Job Satisfaction $\rightarrow$ Employee Performance & 0.163 & 2.452 & 0.015 \\
\hline
\end{tabular}

Source: Processed data, SmartPLS 2021 
Table 6. Indirect Test Results

\begin{tabular}{lccc}
\hline \multicolumn{1}{c}{ Contruct } & Original Sample & $\mathrm{t}-$ Statistic & $\mathrm{p}$-value \\
\hline $\begin{array}{l}\text { Training } \rightarrow \text { Job Satisfaction } \rightarrow \text { Employee } \\
\text { Performance }\end{array}$ & 0.038 & 1.464 & 0.144 \\
$\begin{array}{l}\text { Performance Appraisal } \rightarrow \text { Job Satisfaction } \rightarrow \\
\text { Employee Performance }\end{array}$ & 0.042 & 1.991 & 0.047 \\
$\begin{array}{l}\text { Compensation System } \rightarrow \text { Job Satisfaction } \rightarrow \\
\text { Employee Performance }\end{array}$ & 0.056 & 2.124 & 0.034 \\
\hline
\end{tabular}

Source: Processed data, SmartPLS 2021

\section{Discussion}

\section{Effect of training on employee perfor- mance}

The results of the analysis of research data to see the effect of training on employee performance showed that the $\mathrm{t}$ statistic value was (5.046). The value of the $\mathrm{t}$ statistic is greater than the value of t table (1.98) with a significance value of 0.000 or less than 0.05, meaning that the first hypothesis (a) proposed is accepted, namely that there is an effect of training on employee performance in private hospitals in Indonesia. Surakarta.

Training becomes employee motivation to increase knowledge so that employees can do work with optimal results. Training will improve employee competence so that they can provide good performance for the company. The hospital industry is an industry where its human resources must have certain specifications in doing work. Therefore, in the hospital industry, training is one way that needs to be done in HRMP to be able to improve the performance of its employees. The results of this study are in line with the research (Chełmecka, 2018; Jocom et al., 2017; Karim et al., 2019; Younas et al., 2018; Zhavoronkova et al., 2018).

\section{Effect of performance appraisal on employee performance}

Data analysis to analyze the effect of performance appraisal on employee performance shows that the value of $t$ statistic (2.728). The value of the $t$ statistic is greater than the value of the $t$ table (1.98). The significance value obtained is 0.007 which is smaller than 0.05. The results of the analysis show that the first hypothesis (b) is accepted means that there is an influence of performance appraisal on the performance of employees of the private hospital industry in Surakarta.

Performance appraisal as HRMP needs to be managed optimally. Performance appraisal will describe what the employee has done and whether the work contributes to the company's goals. In the hospital service industry where service is the main thing, it requires employees who can carry out their work professionally. Performance appraisal can motivate employees in carrying out their duties as well as possible so that it will have a positive impact on employee performance. The results of this study are consistent with research (Khan, 2010; Khan. et al., 2018; Meysen et al., 2012).

\section{Effect of compensation system on employee performance}

Analysis of data from research data states that the compensation system on employee performance shows that the $t$ statistic value (3.311) is greater than the $t$ table (1.98) with a significance value of 0.001 less than 0.05. This means that the first hypothesis (c) is accepted, namely the compensation system affect the performance of private hospital employees in Surakarta.

Hospitals as a service industry in the humanitarian field are also required to have quality services. Compensation as the most basic component in HRMP can be an important factor to improve employee performance. Employee performance is an important parameter to support customer 
service. The compensation system affects the productivity of an employee at work. A good compensation system makes employees work better and has a positive impact on their performance. Research results from Hafiza et al. (2011), Hameed (2014), and Siddiqi and Tangem (2018) are in line with this study.

\section{The Role of Job Satisfaction Mediates the Effect of HRMP on Employee Performance}

Several studies show that employee job satisfaction is a company investment. Job satisfaction has become a strong predictor to improve company performance in the long term. Job satisfaction will make employees feel comfortable, happy, and satisfied in their role to complete their tasks with dedication.

The results of data analysis show that training has a significant effect on employee performance (estimated coefficient: 0.235 ; p-value: 0.000 ) but training has no significant effect on employee performance through job satisfaction (estimated coefficient: 0.038; pvalue 0.144 ). This means that the second hypothesis (a) is rejected, which means that job satisfaction cannot mediate the effect of training on employee performance. This study is inconsistent with research that explains that training has an indirect effect on employee performance (Alsafadi \& Altahat, 2021; Azis. et al., 2019; Ingsih et al., 2021; Prasetyo, 2019).

The results of data analysis show that performance appraisal has a significant effect on employee performance (Estimated coefficient: 0.212; p-value: 0.007). The job satisfaction mediation test shows that the influence of performance appraisal has a significant effect on employee performance with job satisfaction as a mediation (estimated coefficient: 0.042; p-value: 0.047). This means that the second hypothesis (b) is accepted, which means that job satisfaction can mediate the effect of performance appraisal on employee performance. Data analysis also shows the role of partial mediation because the estimated coefficient value of the direct effect is greater than the indirect effect. The results of this study are not different from the research conducted by Wandansari (2019) and Ferdiane et al. (2018) which state that performance appraisal can affect employee performance through job satisfaction.

Furthermore, the results of data analysis show that the compensation system affects employee performance (estimated coefficient: 0.275; p-value: 0.001 ) and the mediation test shows that job satisfaction can mediate the effect of the compensation system on employee performance (estimated coefficient: 0.056; p- value: 0.034$)$. The results of this analysis mean that the second hypothesis (c) is accepted, which means that job satisfaction can mediate the effect of the compensation system on employee performance. Data analysis also shows the role of partial mediation because the estimated coefficient value of the direct effect is greater than the indirect effect. The results of this study are consistent with the research of Hartono et al. (2021), Sukidi (2016), and Yudianto and Aryani (2018) which state that the compensation system affects employee performance through job satisfaction because compensation given appropriately will foster a sense of satisfaction with the work of employees and will motivate to achieve organizational targets.

The results of the research analysis see that job satisfaction can play a role in mediating the performance appraisal and compensation system on employee performance. Therefore the company must be able to provide what can make employees feel comfortable and happy in completing their duties. This will have an impact on its performance later. Furthermore, companies need implement HRMP by providing adequate salaries, bonuses, and benefits as well as other compensation systems that can bring job satisfaction to hospital employees so that they can provide good service to patients 
and will ultimately have an impact on the hospital's competitive advantage.

\section{CONCLUSIONS}

This research is expected to provide information related to HRMP and help professionals in the HRM field to be able to improve employee performance, especially in the private hospital service industry through the creation of employee job satisfaction. Based on data analysis with SmartPLS, it is concluded that training, performance appraisal, and compensation system have a significant influence on the performance of private hospital employees in Surakarta. Training will provide new skills to employees and can have an impact on the employee's ability to complete the assigned work so that in the end the employee's performance will increase. Performance appraisals at hospitals are fair and accurate, so employees will feel satisfied and motivated to improve their performance. A good compensation system will ensure fairness between employees and the company. Employees will be compensated according to the performance they have achieved. Therefore, compensation is needed to facilitate the achievement of employee performance.

Meanwhile, job satisfaction can act as a mediating effect between performance appraisal and compensation systems on the performance of employees of a private hospital in Surakarta. However, job satisfaction cannot play a role in mediating employee performance training in a private hospital in Surakarta. Therefore, job satisfaction needs to be maintained or increased in the employee environment through performance appraisal and the provision of a clear compensation system to make employee performance better.

Based on the research findings that have been conducted, the recommendations that may be made are that additional research be undertaken to establish other constructs as predictors of employee performance, such as motivation, leadership, capability, and satisfaction.
Observations show that there is research that supports these factors as antecedents of employee performance. In addition, companies can implement HRMP such as training, performance appraisals, and compensation systems correctly and appropriately because human resources are the biggest resources of a company and need to be managed properly so that later it will have a positive impact on achieving company goals.

\section{REFERENCES}

Allameh, S. M., Barzoki, A. S., Ghazinour, S., Khodaei, S. A., \& Abolghasemian, M. (2014). Analyzing the effect of Employee Engagement on job performance in Isfahan Gas Company. International Journal of Management Academy, 2(4), 20-26.

Alqudah, H., Osman, A., \& Alqudah, H. (2014). The Effect Of Human Resources Management Practices On Employee Performance. International Journal of Scientific \& Technology Research, 3(9), 129-134.

Alsafadi, Y., \& Altahat, S. (2021). Human Resource Management Practices and Employee Performance: The Role of Job Satisfaction. Journal of Asian Finance, Economics and Business, 8(1), 519-529.

Astuti, S. D., Shodikin, A., \& Ud-Din, M. (2020). Islamic leadership, Islamic work culture, and EP: The mediating role of work motivation and job satisfaction Journal of Asian Finance, Economics, and Business, 7(11), 1059-1068. doi:doi.org/10.13106/jafeb.2020.vol7 .no11.1059. 
Aycan, Z., Kanungo, R., Mendonca, M., Yu, K., Deller, J., Stahl, G., \& Kurshid, A. (2000). Impact of culture on human resource management practices: A 10- country comparison Applied Psychology, 49(1), 192-221.

Azis., A. A., Muhibuddin, A., \& Saleh, M. Y. (2019). The Influence Of Motivation, Job Training, And Information Technology To Performance Of Employee Maxone Hotel \& Amp; Delia Resort Makassar Indonesian Journal of Business and Management, 1(1), 0815. doi: https://doi.org/10.35965/jbm.v1i1.20

Bolman, L. G., \& Deal, T. E. (2011). Reframing organizations: Artistry : Choice and leadership: Jossey-Bass.

Bratton, J., \& Gold, J. (2003). Human Resource Management: Theory and Practice (3rd Edition ed.): Hampshire: Palgrave Macmillan.

Cardon, M. S., \& Stevens, C. E. (2004). Managing human resources in small organizations: What do we know? . Human resource management review, 14(3), 295-323.

Carlson, D., Upton, N., \& Seaman, S. (2006). The Impact of Human Resource Practices and Compensation Design on Performance: An Analysis of Family- Owned SMEs. Journal of Small Business Management 44, 531-543. doi:10.1111/j.1540627X.2006.00188.x.

Castilla, E. J. (2005). Social Networks and Employee Performance in a Call Center. American Journal of Sociology, 110(5), 1243-1283.

Chaudhury, S. (2015). Job satisfaction of hospital staff: An emerging challenge Medical Journal of DY Patil University, 8(2), 129-130. doi:10.4103/0975-2870.153135

Chełmecka, A. (2018). Study the relationship between creativity and knowledge. World Scientific News, 92(2), 198-210.
Chukwuka Ernest J. (2016). Effect of Human Resource Management practices on employee performance in Nigerian Public Service. Lambert Academic Publishers, 1(1), 1-7.

Croucher, R., Wood, G., Brewster, C., \& Brookes, M. (2012). Employee turnover, HRM and institutional contexts. Economic and Industrial Democracy, 33(4), 605-620.

Ferdiane, F. F., Setyanti, S. W. H., \& Sudaryanto. (2018). Penerapan Sistem Penilaian Kinerja Dengan Intervening Motivasi Dan Kepuasan Kerja Terhadap Kinerja Karyawan. Jurnal Manajemen dan Kewirausahaan, 6(1), 45-50. .

George, E., \& Zakkariya, K. (2018). Job Satisfaction in the Banking Sector Springer International Publishing.

Ghauri, E. (2012). Improving performance appraisal practices: a multiple case study of the Pakistan pharmaceutical industry.

Ghebregiorgis, F., \& Karsten, L. (2006). Human resource management practices in Eritrea: challenges and prospect. Employee Relations, 28(2), 144-163.

Ghozali., I., \& Latan, H. (2015). Partial Least Squares : Konsep, Teknik dan Aplikasi Menggunakan Program SmartPLS 3.0. Semarang: Universitas Diponegoro.

Hafiza, N. S., Shah, S. S., Jamsheed, H., \& Zaman, K. (2011). Relationship between rewards and employee $\mathrm{s}$ Motivation in the non-profit organizations of Pakistan Business Intelligence Journal, 4(2), 327-338.

Hafiza. N. S, Shah. S.S, Jamsheed. H, \& Zaman. K. (2011). Relationship between rewards and employee ${ }^{\text {ec }} \mathrm{s}$ Motivation in the non-profit organizations of Pakistan Business Intelligence Journal, 4(2), 327-338.

Hameed, A., Ramzan, M., \& Zubair, H. M. K. . (2014). Impact of compensation on employee performance (empirical 
evidence from banking sector of Pakistan). International Journal of Business and Social Science, 5(2).

Hartono, R., Effendi, \& Nurwati, E. (2021). The Effect of Compensation and Motivation on Employee Performance with Job Satisfaction as Intervening Variables at Hotel XYZ, in Jakarta Majalah Ilmiah Bijak, 18(1), $\quad 153 \quad$ - 166. doi:https://doi.org/10.31334/bijak.v1 8i1.1309.g711.

Hassan, S. (2016). Impact of HRM Practices on Employee's Performance International Journal of Academic Research in Accounting, Finance and Management Sciences 6(1), 15-22. doi:DOI: 10.6007/IJARAFMS/v6-i1/1951

Hee, O. C., \& Jing, K. R. (2018). The Influence of Human Resource Management Practices on Employee Performance in the Manufacturing Sector in Malaysia International Journal of Human Resource Studies $8(2)$, 129-147. doi:https://doi.org/10.5296/ijhrs.v8i2 .12826 .

Ingsih, K., Riskawati, N., Prayitno, A., \& Mirpur, S. A. (2021). The Role Of Mediation On Work Satisfaction To Work Environment, Training, And Competency On Employee Performance. Jurnal Aplikasi Manajemen, 19(3), 469-482. doi: http://dx.doi.org/10.21776/ub.jam.20 21.019.03.02

Japlani. A., \& Purnamasari, E., ,. (2020). The influence of Employee Competency, Job Stress, Work Environment, and Performance Appraisal System toward Employee Performance at Kantor Pelayanan Pajak Pratama in Metro. Admisi dan Bisnis, 21(3). doi:http://dx.doi.org/10.32497/ab.v2 $\underline{1 \mathrm{i} 3.2483}$
Jocom, J., Lambey, L., \& Pandowo, M. (2017). The Effect Of Job Rotation And Training On Employee Performance In PT. Pegadaian (Persero) Manado. EMBA Journal, 5(2), 279-288.

Karim, M. M., Choudhury, M. M., \& Latif, W. B. (2019). The Impact Of Training And Development On Employees' Performance: An Analysis Of Quantitative Data. Noble International Journal of Business and Management Research, $3(2), 25-33$.

Khan. (2010). Effects of human resource management practices on organizational performance - an empirical study of oil and gas industry in Pakistan European Journal of Economics, Finance and Administrative Sciences, 24(6), 157174.

Khan., M., Mdyusoff, R., Ismail, F., \& Hussain, A. (2018). The impact of performance appraisal on employee job performance in public sector universities of Khyber Pakhtunkhwa, Pakistan. 7(3.25), 544-548.

Laird, D., Holton III, E. F., \& Naquin, S. S. (2003). Approaches To Training And Development: Revised And Updated: Basic Books.

Mahadevan, A., \& Mohamed, F. A. (2014). Impact Of Human Resource Management (HRM) Practices On Employee Performance (A Case Of Telekom Malaysia). International Journal of Accounting \& Business Management 2(2), 29-42.

Meysen, F., R.J. Mohammad, \& D. Ebrahim. (2012). The Effect of Peformance Appraisal on Employee's Output Implying on the Moderating Role of Motivation in Workplace Internation Journal of Business and Management Tomorrow, 2(4), 1-9. 
Mira, M. S., Choong, Y. V., \& Thim, C. K. (2019). The effect of HRM practices and employees' job satisfaction on employee performance Management Science Letters, 9, 771-786.

Mohamed, F. A. (2014). Impact of Human Resource Management (HRM) Practices on Employee Performance (A case of Telekom Malaysia). International Journal of Accounting \& Business Management, 29-42.

Nor, A. I. (2018). Enhancing Employee Performance through Human Resource Management Practices : A Review Of Literature European Journal Of Human Resource Management Studies, 2(1), 87-96.

Onuorah, A. N., Okeke, M. N., \& Ikechukwu, I. A. (2019). Compensation Management and Employee Performance in Nigeria International Journal of Academic Research in Business and Socal Sciences, 9(2), 384-398.

Pradhan, R. K., Dash, S., \& Jena, L. K. (2017). Do HR practices influence job satisfaction? Examining the mediating role of employee engagement in the Indian public sector undertakings Global Business Review, 20(1), 1-14. doi:https://doi. org/10.1177/0972150917713895

Prasetyo, R. (2019). Pengaruh Pelatihan, Lingkungan Kerja, Dan Budaya Organisasi Terhadap Kinerja Karyawan Dengan Kepuasan Kerja Sebagai Variabel Intervening Di Sekretariat Badan Pelatihan Dan Pendidikan Keuangan (BPPK) Jakarta. (S1 Manajemen). Universitas Islam Indonesia, Yogyakarta. Retrieved from https://dspace.uii.ac.id/handle/12345 6789/14393 (14311035)

Qureshi, M. T., \& Mohammad, R. I. (2006). Impact of Human Resource Management Practices on Organizational Performance in Pakistan Muhammad Ali Jinnah University Islamabad.,
Rahahleh, A. H., Alabaddi, Z. A., \& Moflih, M. A. (2019). The Impact of Performance Appraisal on Employee Performance in Banks Operating in the South of Jordan. International Journal of Human Resource Studies, 9(4).

Rais, S. F., M.S Perdhana, \& Z. Hidayah. (2021). Influence Analysis Of Forced Distribution Rating Performance Appraisal And Merit Pay To Performance Of Directorate General Of Taxes's Employees With Job Satisfaction As Intervening Variable At Blora Tax Service Office. International Journal of Human Capital Management, 5(1), 91-106. doi:https://doi.org/10.21009/IJHCM. $\underline{05.01 .8}$

Rawashdeh, A. M., \& Al-Adwan, I. k. (2012). The impact of human resource management practices on corporate performance: Empirical study in Jordanian commercial banks. African Journal of Business Management 6(41), 10591-10595.

Robbins, S. P., \& Judge, T. A. (2015). Organizational Behavior (17 th ed.): Pearson.

Rodjam, C., Thanasrisuebwong, A., Suphuan, T., \& Charoenboon, P. (2020). Effect of Human Resource Management Practices on Employee Performance Mediating by Employee Job Satisfaction Systematic Review Pharmacy, 11(3), 37-47.

Salmela-Aro, K., \& Nurmi, J. E. (2004). Employees' motivational orientation and well-being at work: A personoriented approach Journal of Organizational Change Management, 17(5), 471-489.

Schuler, R. S., \& Jackson, S. E. (1987). Linking competitive strategies with human resource management practices. The Academy of Management Executive, 1987-1989, 207-219. 
Sels, L., De Winne S., Maes, J., Faems, D., Delmotte, J., Forrier, A. (2003). . (2003). How HRM affects corporate financial performance: Evidence from Belgian SMEs. (Working Paper Steunpunt OOI: 2003.).

Shahzad, K., S. Bashir, \& Ramay, M. (2008). Impact of HR practices on perceived performance of university teachers in Pakistan International review of business research papers, 4(2), 302-315.

Shanty, D., \& Mayangsari, S. (2017). Analisis Pengaruh Kompensasi, Motivasi, Lingkungan Kerja Terhadap Kinerja Karyawan Dengan Komitmen Organisasional Sebagai Variabel Intervening. Jurnal Informasi Perpajakan Akuntansi Dan Keuangan Publik 12(2). doi:http://dx.doi.org/10.25105/jipak. v12i2.5114.

Shaukat, H., Ashraf, N., \& Ghafoor, S. (2015). Impact of Human Resource Management Practices on Employees Performance Middle-East Journal of Scientific Research, 23(2), 329-338.

Siddiqi, T., \& Tangem, S. (2018). Impact Of Work Environment, Compensation And Motivation On The Performance Of Employees In The Insurance Companies Of Bangladesh. South East Asia Journal of Contemporary Business, Economics and Law, 15(5), 153-162.

Singh, K. (2004). Impact of HR practices on perceived firm performance in India. . Asia Pacific Journal of Human Resources 42(3), 301-317.

Subekti, A. (2021). The Influence Of Performance Appraisal System Towards Job Satisfaction, Motivation, As Well As Employee Performance International Journal of Economics, Business and Accounting Research, 5(2), 104-114. doi:10.29040/ijebar.v5i2.2484.
Sukidi, F. W. (2016). The Effect of Motivation, Compensation, and Job Satisfaction on Employee Performance with Job Satisfaction as an Intervening Variable. Journal of Resource Management Economics, 18(2), 79-91.

Taib, N. M., Mohamad Nasir Saludin, M. N., \& Hanafi, W. N. W. (2018). The Effects of Human Resources Management (HRM) Practices on Employee Performance with the Mediating Role of Employee Engagement Selangor Business Review, 3(1), 46-60.

Tessema, M., \& Soeters, J. (2006). Challenges and prospects of HRM in developing countries: testing the HRM performance link in Eritrean civil service International Journal of Human Resource Management, 17(1), 86-105.

Tzafrir, S. (2005). The relationship between trust, HRM practices and firm performance The International Journal of Human Resource Management, 16, 1600-1622. doi:10.1080/09585190500239135

Wan, D., Kok, V., \& Hong, C. H. (2002). Strategic Human Resource Management and Organizational Performance in Singapore Compensation and Benefits Review Saranac, 39(4), 836-866.

Wandansari, W. (2019). The Effect Of EPerformance Appraisal System And Additional Income Of Civil Servant On Performance With Job Satisfaction As Intervening Variable In The Regional Secretariat Of Mojokerto City Airlangga Development Journal, 3(2), 162-179.

Younas, W., Farooq, M., Khalil-UrRehman, F., \& Zreen, A. (2018). The Impact of Training and Development on Employee Performance. IOSR Journal of Business and Management 20(7), 20-23. 
Yudianto, S., \& Aryani, D. N. (2018). The Influence of Compensation, Motivation and Work Environment on Performance with Job Satisfaction as Intervening Variable (A Study at Secretariate of Pasuruan Regency). International Journal of Trend in Scientific Research and Development 2(5), 2194-2201. doi:https://doi.org/10.31142/ijtsrd18 252

Zhavoronkova, G., Zavalko, K., \& Zhavoronkov, V. (2018). Knowledge, Creativity, And Innovation In Knowledge Society Formation. International Scientific Journal 12(9), 367-370. 